\title{
Assessment of Liquidity Ratios as Indicators of an Organization's Economic Security: Accounting Aspects
}

\author{
Svetlana A. Boronenkova \\ Ural State University of Economics \\ Yekaterinburg, Russia
}

\author{
Olga A. Mironova \\ Volga State University of Technology \\ Yoshkar-Ola, Russia
}

\author{
Aleksey Yu. Popov \\ Ural State University of Economics \\ Yekaterinburg, Russia \\ prepodpopov@yandex.ru
}

\begin{abstract}
The paper provides an overview of the organization's indicators of economic security proposed by various researchers, as well as evaluates the impact of the accounting policies of an economic entity and the professional judgment of an accountant on the formation of key indicators of an enterprise's economic security - liquidity ratios. The main theses in relation to the formation of balance sheet items used to calculate liquidity ratios have been disclosed, and the problems in relation to the formation of a number of papers have been identified, taking into account the norms of the current accounting legislation and the prevailing practice in Russia in the formation of financial statements. The considered features of calculating financial reporting indicators, included in the calculation of liquidity ratios, justify the $n$ need to consider the variability of the formation of indicators and the inadmissibility of a formalized approach to their assessment. Accordingly, in order to make informed decisions regarding the management of the organization and ensure its economic security, it is necessary to take into account the provisions of the accounting policy, especially the economic activities of the organization and the principles used by the organization for the formation of financial statements.
\end{abstract}

Keywords-economic security; indicators of economic security; liquidity ratios; financial statements; accounting policy; professional accountant judgment.

\section{INTRODUCTION}

Under the unstable economic situation, economic sanctions, unpredictable changes in exchange rates, increased competition, and other unfavorable factors for business development, issues of economic security of an economic entity are becoming increasingly important. For a modern organization, it is important not only to maintain its position in the market, to maintain its solvency, liquidity, and financial stability, but also to increase operational efficiency and increase profitability, thereby ensuring the economic growth of the industry and the economy as a whole. In this regard, the work of a number of Russian economists, in particular
T.F. Ryabova, T.M. Kryukova, I.N. Sannikova, N.S. Bezuglaya, A.V. Gukova, O.A. Ryazanova, and others [1-6]. The theses defended on the indicated problem deserve attention, in particular V.N. Zubenko, L.S. Yakovlev, A.V. Kashin, D.A. Maksimov, and others [7-10]. Foreign experience in assessing the economic security of organizations described in the works of R. Dwivedi, W. Gereluk, K. Scheve, J.E. Stiglitz, and others, is of particular scientific interest [1114]. Moreover, under the development of the economy digitization, the indicators of economic security of organizations, calculated according to the financial statements of organizations, are almost completely accessible to external users of financial information, in particular, in online settlement account management systems, most banks, when making a payment, evaluate the counterparty's reliability level at the time the payment order is generated to pay the counterparty cash; Kontur-focus, SPARK, SBIS, etc. systems allow you to evaluate various financial indicators from the point of view of economic security of concluding contracts with the organization, since the financial reporting data are open information and, using software algorithms, the necessary indicators are calculated automatically. At the same time, each automation and control system evaluates the level of reliability of a business entity based on data laid down by the developers of the corresponding software, while uniform approaches to assessing economic security indicators are not currently normatively approved and can be calculated in multiple variations. The indicated problems are reinforced by the variability of the calculation of certain economic security indicators, in particular liquidity ratios, as well as the variability of the formation of financial statements based on the provisions of the accounting policy of an economic entity.

Proceeding from the information specified in this paper, the goal is to consider the formation of the organization's liquidity ratios as indicators of its economic security, according to financial statements using digital technologies, as well as assess the impact of accounting policies on the organization's economic security indicators. 
In order to achieve this goal, the tasks to determine the definition of economic security of the enterprise used in the paper, systematize financial indicators of economic security and identify key indicators, assess the impact of accounting policies of an economic entity on these indicators in order to develop practical recommendations on the use of these indicators in analyzing activities of the enterprises, and assessment of its economic security have been set and solved.

\section{RESEARCH METHODOLOGY}

The study is based on general scientific and special methods: observation, critical analysis, generalization, hypothesis, analogy, etc. When formulating the goal, the hypothesis originally put forward suggests that, according to the financial statements, it is possible to objectively evaluate liquidity ratios that are indicators of the economic security of an enterprise and develop a set of measures to reduce possible threats to the organization.

The scientific novelty of the study lies in the theoretical and methodological justification for assessing the impact of the accounting policies of economic entities on indicators of their economic security in order to clarify the principles of the formation and analysis of these indicators when making decisions to reflect threats and ensure sustainable development.

\section{RESEARCH RESULTS}

To date, a unified approach to identifying the definition of economic security of an organization has not been developed in domestic science. This issue is considered by a number of domestic researchers, such as E.B. Dvoryadkina, G.B. Kleiner, E.A. Oleinikov, and others [15-17]. Since the analysis of the definitions of this concept is beyond the scope of this work, in this paper, we will determine the economic security of the enterprise as a state of protection from various external and internal threats, ensuring efficient management at the present time and having the prerequisites for sustainable development and increased efficiency in the future. Economic security assessment is carried out using various indicators. T.Yu. Krotenko defines indicators of economic security as indicators whose violation leads to the development of negative crisis trends in the field of economic security [18].

Different economists offer different types of economic security ratios of the enterprise in their works. In particular, Sannikova I.N. and some other authors group these indicators into three groups: financial, production, and personnel [3]. S.G. Simonov grouping produces indicators of financial stability, indicators of technical condition and movement of fixed assets, indicators of human resources and personnel policy [19]. The proposed groups have scientific justification, but at the same time, they can be criticized, since one indicator can relate to several groups at once, for example, the indicator of labor productivity, on the one hand, is a financial indicator, on the other hand, is a personnel indicator, and on the third hand - a production one. Similarly, the depreciation of fixed assets is simultaneously financial, because it is based on the assessment of fixed assets, and, on the other hand, a production one, characterizing the degree of use. In this work, the emphasis is placed on the financial indicators of economic security. Let us review them from the point of view of various researchers in Table 1.

TABLE I. REVIEW OF ECONOMIC SECURITY RATIOS OF THE ORGANIZATION OFFERED BY ECONOMISTS

\begin{tabular}{|c|c|}
\hline Author and source & $\begin{array}{l}\text { Economic security indicators proposed } \\
\text { by the authors }\end{array}$ \\
\hline $\begin{array}{l}\text { Ryabova T.F., } \\
\text { Kolpakova T.V. The Choice } \\
\text { of a System of Indicators } \\
\text { Characterizing the Level of } \\
\text { Economic Security of the } \\
\text { Organization. Economic } \\
\text { Bulletin of Rostov State } \\
\text { University. 2007. Vol. } 5 \text {. } \\
\text { No. 4-3. Pp. 315-320. }\end{array}$ & $\begin{array}{l}\text { The minimum level of capacity } \\
\text { utilization, sufficient for the cost- } \\
\text { effective operation of the company; } \\
\text { The share of energy in the cost of } \\
\text { production; } \\
\text { Profitability level; } \\
\text { The ratio of accounts payable and } \\
\text { receivable; } \\
\text { The ratio of the average salary in the } \\
\text { company and the average in the Russian } \\
\text { economy; } \\
\text { The level of salary arrears, etc. [1] }\end{array}$ \\
\hline $\begin{array}{l}\text { Bezuglaya N.S. Economic } \\
\text { Security of the Enterprise: } \\
\text { Indicators and Assessment. } \\
\text { Rhizomatic Logic and } \\
\text { Economic Security of the } \\
\text { Enterprise. Russian } \\
\text { Entrepreneurship. } 2010 . \\
\text { No. 8-1. Pp. 62-68. }\end{array}$ & $\begin{array}{l}\text { Capital productivity; } \\
\text { Capital-output ratio; } \\
\text { Capital intensity of production; } \\
\text { Labor productivity; } \\
\text { Profitability of production; } \\
\text { Financial stability of the enterprise; } \\
\text { Level of solvency of the enterprise; } \\
\text { Balance sheet structure; } \\
\text { Innovative activity [4] }\end{array}$ \\
\hline $\begin{array}{l}\text { Ryazanova O.A., } \\
\text { Kochetkov M.N. The } \\
\text { Concept, Essence, and } \\
\text { Indicators of the Financial } \\
\text { Component of the Economic } \\
\text { Security of the Enterprise. } \\
\text { Economics and Management: } \\
\text { Problems, Solutions. 2017. } \\
\text { Vol. 2. No. 12. Pp. 109-114. }\end{array}$ & $\begin{array}{l}\text { Liquidity and solvency; } \\
\text { Financial stability; } \\
\text { Business activity; } \\
\text { Profitability; } \\
\text { Creditworthiness; } \\
\text { Labor productivity (in terms of value); } \\
\text { Availability of own investment } \\
\text { resources; } \\
\text { Investment activity [6] }\end{array}$ \\
\hline $\begin{array}{l}\text { Sannikova I.N. Indicators of } \\
\text { Economic Security of the } \\
\text { Enterprise. Management of a } \\
\text { Modern Organization: } \\
\text { Experience, Problems, and } \\
\text { Prospects. 2017. No. } 2 \text { (8). } \\
\text { Pp. 204-209. }\end{array}$ & $\begin{array}{l}\text { Absolute liquidity ratio; } \\
\text { Current ratio; } \\
\text { Profitability of production; } \\
\text { Capital intensity of production; } \\
\text { Overdue receivables and accounts } \\
\text { payable; } \\
\text { Ratio of own and borrowed funds [3] }\end{array}$ \\
\hline $\begin{array}{l}\text { Dvoryadkina E.B. Economic } \\
\text { Security [Text] : Training Aid } \\
\text { / E. B. Dvoryadkina, Ja. P. } \\
\text { Silin, N. V. Novikova ; } \\
\text { Ministry of Education and } \\
\text { Science of the Russian } \\
\text { Federation, Ural State } \\
\text { University of Economics. - } \\
\text { 2nd ed., revised and } \\
\text { supplemented. - } \\
\text { Yekaterinburg: [Ural State } \\
\text { University of Economics } \\
\text { Press], 2016. - } 194 \text { pp. }\end{array}$ & $\begin{array}{l}\text { Liquidity ratios: } \\
\text { - total liquidity ratio; } \\
\text { - absolute liquidity ratio; } \\
\text { - quick ratio; } \\
\text { - current ratio; } \\
\text { - ratio of absolute balance sheet } \\
\text { liquidity. } \\
\text { Profitability ratios: } \\
\text { - return on current assets; } \\
\text { - profitability of core business; } \\
\text { - return on sales; } \\
\text { - return on total assets. } \\
\text { Financial stability ratios: } \\
\text { - coefficient of autonomy; } \\
\text { - ratio of borrowed and own funds; } \\
\text { - equity ratio; } \\
\text { - ratio of financial independence [15]. }\end{array}$ \\
\hline $\begin{array}{l}\text { Simonov S.G. The Economic } \\
\text { Security of Small Businesses } \\
\text { [Text]: Textbook for High } \\
\text { Schools. Simonov S.G., } \\
\text { Makhmudova M.M., } \\
\text { Khamathanova M.A. } \\
\text { Tyumen: Tyumen State Oil } \\
\text { and Gas University. } 2015 . \\
240 \text { pp. }\end{array}$ & $\begin{array}{l}\text { Absolute liquidity ratio; } \\
\text { Marginal liquidity ratio; } \\
\text { Current ratio; } \\
\text { Equity ratio; } \\
\text { Ratio of security of current assets of } \\
\text { source of working capital; } \\
\text { Ratio of provision of stocks and costs } \\
\text { with their source of working capital } \\
\text { [19] }\end{array}$ \\
\hline
\end{tabular}


As can be seen from the table, most authors primarily refer the liquidity ratios of the organization, which should correspond to the established threshold values, to the economic security indicators. The optimal values of liquidity ratios allow the company to timely pay for its obligations, reflecting the threat of bankruptcy. Liquidity ratios, like most other indicators proposed by researchers, are calculated, according to the financial statements of organizations. Moreover, the financial statements of Russian companies are prepared in accordance with the unified methodological norms and rules provided for:

- Federal Law on accounting No. 402-FZ dated December 6, 2011;

- Statement on Accounting and Financial Reporting in the Russian Federation (Order of the Ministry of Finance No. 34n dated 29 July, 1998);

- Statement on Accounting Accounting Statements of the Organization (SOA 4/99);

- Order of the Ministry of Finance of the Russian Federation No. 66n On the Forms of Financial Reporting of the Organization.

The financial reporting indicators are compiled according to the accounting data for the reporting period, and in addition, largely based on the professional judgment of the accountant, since some financial reporting indicators are not directly reflected in the accounting accounts or are reflected, but in the amount of estimated indicators formed on the basis of professional experience and qualifications of the chief accountant. When generating accounting data, the organization follows the accounting policy adopted by it, which ensures the most efficient accounting and ensures the formation of accounting information reliable from the point of view of the organization. However, the accounting policy can have a significant impact on the financial reporting indicators and on the economic security ratios, respectively, since it also represents the choice of one of the accounting options provided for by accounting standards.

Let's demonstrate the impact of accounting policies on the formation of liquidity ratios of an organization.

As a general rule, the absolute liquidity ratio is the ratio of the amount of cash and short-term financial investments to the amount of current liabilities.

Moreover, if the balance of funds reflected in the financial statements is an absolute value that is not affected by either the accounting policy or the professional judgment of the accountant, then with respect to the indicator of short-term financial investments, the accounting policy of the business entity can include options:

- In accordance with SOA 19/02, when forming the initial cost of financial investments, an organization can include the costs associated with their acquisition, in addition to the contractual value, in the initial cost of these assets, and can include them in other expenses;

- In respect of debt securities for which the current market value is not determined, the organization can indicate them at their initial value, and can also write off the difference between the initial value and par value in other income or expenses evenly during the circulation period;

- In respect of financial investments for which the current market value is not determined, the organization shall check these assets for impairment and, if there is any indication of impairment, indicate the decrease in value in the financial statements, in accordance with SOA 10/99 and IFRS 9.

With regard to the accounting assessment of current liabilities, there are also certain problems: in addition to traditional accounts payable, which should be assessed by the organization based on accounting data recognized by the organization as correct, they also include the value of estimated liabilities calculated according to the rules of SOA $8 / 2010$ by various methods: based on the arithmetic mean value, weighted average value, or in other ways. At the same time, the estimated liability should most accurately reflect the amount of necessary funds for its repayment, but since at the time of preparation of the financial statements, this value is not known exactly (otherwise the obligation would not have been recognized as estimated), the organization uses various methods for valuing them based on various factors. In particular, when forming an estimated obligation to pay for vacations not used at the end of the year, most accounting software packages provide for the calculation of these obligations based on the average earnings for each employee and the number of vacation days due to him/her on the reporting date.

In addition, as part of short-term liabilities, the balance sheet gives a discussion indicator of deferred income, which should include government aid indicators, taken into account in accordance with SOA 13/2000, the value of gratuitously received values not used at the end of the reporting period in economic activity, the difference between the market value presented to recover shortages and its book value, and some other indicators.

The debatability of this indicator lies in the fact that the current accounting standards do not spell out the definition and composition of these liabilities and in the current accounting standards SOA 4/99 and SOA 13/2000, this category is only mentioned. At the same time, the instruction to the Chart of Accounts in the description of the scheme of the account 98 operation is outdated in certain aspects, in particular, funds received for future periods (rent or apartment fee, utility bills, revenue for freight transportation, for the transportation of passengers on monthly and quarterly tickets, monthly subscription for the use of communications, etc.) are advances received and are shown in accounts payable, and not in deferred income. The Order of the Ministry of Economic Development of the Russian Federation dated April 21, 2006, No. 104 On Approval of the Methodology for the Federal Tax Service Accounting and Analysis of the Financial Condition and Solvency of Strategic Enterprises and Organizations recommends excluding this indicator from the calculation of liquidity ratios, however many authors ignore this recommendation in their writings.

In order to calculate the critical (quick) liquidity ratio, also called the interim coverage ratio, the ratio of current assets, 
excluding inventories, to the amount of current liabilities is used. That is, in contrast to the absolute liquidity ratio, the numerator includes receivables and other current assets. Also debatable is the issue of including in the calculation of this indicator the item of VAT on acquired values, since the reason for the existence of this ratio in the balance sheet depends not so much on the speed of circulation of the organization's economic assets, but on the efficiency of the organization of the workflow, the terms of contracts with contractors, and the tax policy of the organization. That is, the availability of balances under this item can occur in cases of non-deduction of VAT on acquired assets in accordance with Articles 171, 172 of the Tax Code in the absence of invoices for purchased goods, works, services (document flow factor), and accounts payable for purchased goods, works, and services for which the organization is a tax agent, for example, when acquiring property from foreign suppliers, renting state and municipal property, etc. (contractual policy factor), as well as transfer of future tax deductions, when in the current period, the amount of deductions exceeds the threshold value taken into account by the Federal Tax Service when planning the concept of assignment of field tax audits (89\% of the accrued amounts).

The main item of the balance sheet, which affects the critical (quick) liquidity ratio, is receivables. The general approach to the accounting assessment of accounts receivable is prescribed in Clause 73 of the Statement on Accounting and Financial Reporting in the Russian Federation, according to which the debt is reflected in the amounts formed on the basis of the accounting data recognized as reliable by the reporting organization.

At the same time, Clause 70 of the aforementioned Statement provides for the obligation of business entities to form the debt service reserve balance for debts recognized as doubtful. At the same time, the amount of the debt service reserve balance, which reduces the balance sheet value of receivables, is determined by the organization independently based on the analysis of the financial position of the debtor, its solvency, and the likelihood of a favorable forecast for debt repayment. Moreover, if the financial position of the debtor can be analyzed according to open financial statements, then the assessment of the probability of debt repayment is a completely subjective factor that directly depends on the data available to the organization and its approaches. In this regard, when assessing the organization's accounts receivable, including for calculating liquidity ratios, the accounting policy regarding the formation of the debt service reserve balance for doubtful debts, as well as other aspects affecting the accounts receivable indicators should be analyzed for making informed decisions and formulating conclusions.

The next liquidity ratio is the current liquidity ratio, calculated as the ratio of all current assets, according to the balance sheet to short-term liabilities (excluding deferred income). That is, in contrast to the critical liquidity ratio, the numerator of the formula also takes into account inventories, which in many enterprises have a high proportion in all assets. According to SOA 5/01, inventories include directly materials, finished products and goods, but when forming the "Inventory" indicator in the balance sheet, the balance should include the remnants of work in progress, semi-finished products of own production, special equipment, and special clothing, and some other types of property.

When assessing the inventories, the main approach formulated by SOA 5/01 provides for the assessment of acquired inventories at the actual cost of acquisition, which is the sum of the actual costs of their production and manufacturing, however, in some cases, exceptions are possible. In particular, trade organizations have the right to evaluate goods purchased for resale at the acquisition cost (purchase price), including delivery costs and other costs associated with the acquisition, other than the contractual value, as part of the sale expenses, which is subsequently written off to reduce the financial result.

For production organizations, the estimation of work in progress indicators is carried out depending on the type of activity and also provides for the variability provided for by the Order of the Ministry of Finance No. 34n. According to it, in industrial organizations with a mass and serial nature of production, the indicators of work in progress can be calculated:

- based on the actual or normative (planned) production cost;

- by the amount of direct costing items;

- by the cost of raw produce, materials, and semi-finished products used in production.

In organizations with a single nature of production, which usually use an order-based cost accounting method, work in progress is recognized in the accounting and financial statements for the costs actually incurred at the reporting date.

The recognition of other current assets in the calculation of liquidity ratios is also a debatable point. Accounting legislation prescribes to reflect under this asset item all other types of current assets that are not included in other groups of asset items of current assets. In particular, it can reflect the amount of deferred expenses, which, in accordance with applicable law, can be formed under contracts in accordance with SOA 2/2010 for the amount of future expenses associated with the conclusion of a construction contract, as well as in accordance with SOA 15/2008, the amount of other expenses on loans and credits that the organization has the right to take into account other expenses during the term of the loan agreement (loan agreement).

However, in accordance with domestic accounting practice, many enterprises state indicators that do not fully meet the criteria of assets, for example, the amounts of VAT calculated from advances received (account balance 76.AB), as well as the amounts identified at the reporting date shortage of proceedings that are not settled at the end of the reporting period in this asset. If these amounts are insignificant in the calculation of liquidity ratios, they can be neglected; however, if they are substantial, these indicators can significantly affect both liquidity ratios, which are ratios of economic security, and indicators of financial condition as a whole. 
[4] Bezuglaya N.S. Economic Security of the Enterprise: Indicators and Assessment. Rhizomatic Logic and Economic Security of the Enterprise. Russian Entrepreneurship. 2010. No. 8-1. Pp. 62-68.

Thus, based on the above features of data generation for calculating liquidity ratios, a principle is formulated according to which, under the digitization of the economy, when the calculation of many ratios and indicators is carried out automatically, a formal approach to their analysis and assessment of threshold values is unacceptable, since the accounting policies, the professional judgment of the accountant, and the characteristics of the economic activity of the organization have a very significant effect on the indicators formed. When making decisions on providing the organization with resources, on taking measures ensuring economic security, developing decisions aimed at the sustainable development of the organization and increasing the efficiency of its activities, it is necessary to analyze in more detail the performance ratios and indicators of economic security for their formation, since in some cases, the method of calculating indicators operates on generally accepted asset items of financial statements, but on several occasions, the content of the asset items is subject to significant variability.

\section{CONCLUSION}

The promising areas for the development of economic science include further unification of the calculation of performance indicators for comparison with threshold values of economic security ratios, as well as further improvement of the rules and principles of accounting and the formation of financial statements, which will allow to objectively evaluate the results of operations, financial condition in order to ensure economic security and the development of measures to protect against external and internal threats.

\section{References}

[1] Ryabova T.F., Kolpakova T.V. The Choice of a System of Indicator Characterizing the Level of Economic Security of the Organization. Economic Bulletin of Rostov State University. 2007. Vol. 5. No. 4-3. Pp. 315-320.

[2] Kryukova T.M., Stroyev A.Yu. The Impact of the Introduction of Risk Indicators on the Economic Security Formation of the Enterprise. In the collection: Economic Security of Russia: Problems and Prospects Materials of the V International Scientific and Practical Conference of Scientists, Specialists, University Professors, Graduate Students, Students. 2017. Pp. 285-288.

[3] Sannikova I.N. Indicators of Economic Security of the Enterprise. Management of a Modern Organization: Experience, Problems, and Prospects. 2017. No. 2 (8). Pp. 204-209.
[5] Gukova A.V., Anikina I.D. Financial Security Indicators of the Enterprise. National Interests: Priorities and Security, No. 25 (11). 2007. Pp. 49-52.

[6] Ryazanova O.A., Kochetkov M.N. The Concept, Essence, and Indicators of the Financial Component of the Economic Security of the Enterprise. Economics and Management: Problems, Solutions. 2017. Vol. 2. No. 12. Pp. 109-114.

[7] Zubenko V.N. Adaptation of Methods for Calculating Threshold Values of Economic Security Indicators in the Industrial Sector (for example, the Stavropol Krai). Abstract of a Thesis for a Candicate Degree in Economics / Stavropol State University. Stavropol, 2011.

[8] Yakovlev G.S. Economic Security of Enterprises in Terms of Conversion (for example, Enterprises of the Military-Industrial Complex of Nizhny Novgorod Region). Thesis for a Candicate Degree in Economics. Nizhny Novgorod, 1999.

[9] Kashin A.V. Economic Security of the Enterprise: Manageria Decisions. Abstract of a Thesis for a Candicate Degree in Economics. Institute of Economics of the RAS. Moscow. 2008.

[10] Maksimov D.A. Models and Methods for Managing the Economic Security of the Enterprise. Thesis for a Candicate Degree in Economics. Plekhanov Russian University of Economics. Moscow. 2011.

[11] Dwivedi, R. 2002. "Models and methods in development-induced displacement", in Development and Change, Vol. 33, No. 4, pp. 709 772 .

[12] Gereluk, W.; Royer, L. 2002. Sustainable Development of the Global Economy: A Trade Union Perspective, SES Paper No. 19 (Geneva, ILO).

[13] Scheve, K.; Slaughter, M. J. 2002. Economic Insecurity and the Globalization of Production, NBER Working Paper 9339 (Cambridge, MA, National Bureau of Economic Research).

[14] Stiglitz, J. E. 2000. "Capital market liberalization, economic growth, and instability", in World Development, Vol. 28, No. 6, pp.1075-1086.

[15] Dvoryadkina E.B. Economic Security [Text] : Training Aid / E. B. Dvoryadkina, Ja. P. Silin, N. V. Novikova ; Ministry of Education and Science of the Russian Federation, Ural State University of Economics. $-2^{\text {nd }}$ ed., revised and supplemented. - Yekaterinburg: [Ural State University of Economics Press], 2016. - 194 pp.

[16] Kleiner G.B. A Strategy of an Enterprise. M.: Publishing House: Delo, 2008. $568 \mathrm{pp}$.

[17] Economic and National Security: Textbook / Ed. by E.A. Oleinikov. M.: Examen, 2005. 768 pp.

[18] Krotenko T.Yu. Methodological Approaches to the Development of Economic Security Ratios of the Organization // University Bulletin. 2018;(11):18-22. https://doi.org/10.26425/1816-4277-2018-11-18-22

[19] Simonov S.G. The Economic Security of Small Businesses: Textbook for High Schools. Simonov S.G., Makhmudova M.M., Khamathanova M.A. Tyumen: Tyumen State Oil and Gas University. 2015. 240 pp. 